part of the vehicle, as the axle of the front wheels for example, and of a shoot or collector of some flexible waterproof material, attached at one end to the breech strap or its equivalent and at the other end to an outlet tube extending from the top of the receiver in the direction of the animal's breech. The receiver or dung trap contains an open-topped drawer or removable lining, which can be withdrawn and replaced by its handle at the back of the receiver. The shoot or collector has an expanded trough-like shape near the breech just large enough to catch the dung, but narrows down to the diameter of the inlet tube. The inlet tube is pivoted to the top of the receiver in such a manner that the shoot will always adjust itself to extend in a straight line from the breech strap, notwithstanding the variations in the heights of different horses.

Whether the animal is standing or running, its dung (and its urine in the case of a mare) is caught by the shoot or collector and travels by gravity along the same into the removable drawer, which can be removed, emptied, and cleaned periodically. With regard to the urine of a male animal, if desired, a funnel-shaped receptacle may be arranged in the proper position to catch the urine and convey it by means of a rubber tube into the dung trap or separate receptacle. There is also a valvular arrangement at the inlet tube of the receiver to allow the dung and urine to pass freely into the receiver, but to prevent any smell coming ont. The shoot and receiver are permanently fastened together and to the carriage. When a horse is put to the carriage, all that is required is to attach the shoot by means of clamps or straps and buckles, which can be done in a couple of minutes. It will be seen that, with the exception of the receiver which is placed quite out of the way, everything is soft and flexible, and as no part of it touches the horse there is nothing in the least to frighten the most timid animal.

The only possible objection that I can see is its unusual or novel appearance. A glance at the photograph will show that it is not very obtrusive or ugly, and I think, considering its great utility, people will soon get used to its appearance as they have to the splashboard or any other necessary part of a carriage. I am convinced that if this apparatus were universally adopted the streets of towns would become almost as clean and as wholesome as a garden walk, disease and mortality would diminish, and the comforts of town life would considerably increase. I do not enter into the economical question for that will at once suggest itself to municipal authorities, the enormous expense of scavenging the streets being necessitated mainly by horse dung.

I am, Sirs, yours faithfully,

J. A. Calantarinnts, M.D. Edin.

Scarborough, Sept. 29th, 1903.

* * The apparatus as shown in the photograph is not at all obtrusively noticeable.-ED. L.

\section{WHAT IS SCIATICA?}

\section{To the Editors of THE LANCET.}

SIRS,-Dr. W. Bruce, in his letter in THE LANCET of Sept. 12th, p. 785, shows that he has not quite grasped either the substance or the spirit of my letter of August 29th p. 633. I, like many other general practitioners, scan weekly the columns of THE LANCET to keep myself acquainted early with any new light thrown on disease or injury, and a pape like Dr. Bruce's professing to revolutionise our conception of sciatica is well calculated to attract the attention of the general practitioner. Sciatica is a common and frequently an intractable complaint, and if Dr. Bruce has given us a clue to its more effectual treatment he is worthy of our gratitude.

Having read Dr. Bruce's paper I was prompted to give details of a case on which his theory had direct bearing. A man with double arthritis deformans affecting the hip-joints is a martyr to sciatica; he sustains an intracapsular fracture of the left femoral neck, union is not good, but the sciatica on that side is cured. Three years later he gets an intracapsular fracture of the right femoral neck and comes into my hands. He is treated with extension; union is fair and the sciatica is cured this side also. $I$ ask if the sciatica was cured by the long rest or the long stretching of the sciatic nerve? I cannot believe that an intercapsular fracture with a few weeks' rest will cure oldstanding arthritis deformans of a joint and if it will not, surely the cure must be attributed to the stretching.

I believe it is an accepted pathological doctrine that the group of toxins which produce an arthritis deformans may also produce a neuritis and the facts of the case seem to me to warrant the opinion that while the sciatica was no doubt in the first place excited by the joint disease there was an actual neuritis of the sciatic nerves which was benefited, as other cases of sciatica have been benefited, by stretching.

Dr. Bruce in his letter confesses that he may have put his case too strongly and thereby relieves me of the onus of suggesting that he has fallen into the common temptation of the man who has a new truth to tell, the temptation of overstating his case for the sake of emphasis. I may be wrong, but it seems to me also that he has not kept quite clear of partisanship in the strife between consulting physician and surgeon which prompts the one to declare that surgeons are prepared to use the knife for every complaint under the sun and the other to refer to the post-mortem room as the "physician's operating theatre." Therefore, to return to Dr. Bruce's use of the term "barbarous" as applied to an operation, I can only repeat , hat unless he has an alternative to offer he has no right bimself to apply the term but should leave it to futurity. Dr. Bruce assumes, withont any ground for the assumption beyond my not mentioning the fact specifically, that the first fracture in my case was not treated by extension. I did not think it necessary to mention its treatment, but as a matter of fact it was not treated by a prescription but by extension, as is customary, the bad result being ascribed to the man's constant restlessness from the sciatica in his other leg.

In concluding let me once more assure Dr. Bruce that his paper has provided me with most interesting and suggestive reading which I have no doubt will be of great use to me practically. I am not presuming to pit my knowledge and experience against his but have written furely from the point of view of the general practitioner, to which class of the profession his paper mostly appeals. Few of us care to undertake such operations as stretching of the sciatic nerves or, $a$ fortiori, removal of the Gasserian ganglion, but the responsibility of sending the patient to the surgeon or the physician is ours. I think Dr. Bruce has on the whole scored a success for the physicians.

$$
\begin{aligned}
& \text { I am, Sirs, yours faithfully, } \\
& \text { Hampstead, Sept. 21st, } 1903 .
\end{aligned}
$$

\section{THE PROBABLE ACTION OF CANCER PARASITES ON THE HUMAN BODY.}

\author{
To the Editors of THE LANCET.
}

SrRS,-Virchow's artificial histological classification of tumours into homologous and heterologous growths has obscured the intellects of medical men with regard to cancerous and other malignant disease for a considerable time. But of late years there has been a tearing away from dogma and there is at present a strongly growing belief that malignant growths are caused by protozoal parasites. I believe that most of the evidence we at present possess, without conclusively proving this to be the case, strongly points that way. Allowing for the moment that cancer is a parasitic disease how can its peculiarities be explained? The most valuable theories are those which connect all the known facts of a subject. When all known facts will not fit in with a theory then it must be wrong. I think in the following all the known facts of cancerous diseases fit. The cancer parasites attack only living epithelial cells. Under favourable conditions they enter some of these cells, live with them symbiotically, dominate them, and stimulate them to increase and to multiply abnormally and thus is formed the primary tumour. Under the malign influence of the parasites the epithelial cells turn arrant traitors to their commonwealth and, like all renegades, become the bitterest foes of that to which they owe allegiance. After a time the dual semi-alien settlement sends forth colonies through the lymph streams which form other settlements wherever they can succeed in getting a foothold-secondary growths. The renegade epithelial cells and their guests prey on the tissues of the body and poison the sources of life by their combined excreta and lead to the destruction of the commonwealth-the human organism. The stroma of cancer is the results of the efforts made by the connective-tissue cells to combat the invaders after the latter have gained a lodgment. The species of parasites which cause sarcoma attack only the connective-tissue cells which 